\title{
Voicing Mathematics Teachers: A Holistic Overview of Their Early Career Challenges
}

\author{
Özge Keskin ${ }^{1}$ \\ Bilkent University
}

\author{
M. Sencer Çorlu ${ }^{2}$ \\ Bahçeşehir University
}

\author{
Alipaşa Ayas $^{3}$ \\ Bilkent University
}

\begin{abstract}
Teachers' further success in and commitment to their profession are shaped by their experiences in the early years of their careers. Being aware of the challenges that novices face would be helpful for teacher-educators in a way that would support pre-service teachers thoroughly. The goal of the current research is to ascertain the perceptions of secondary-school mathematics teachers about the challenging experiences at the beginning of their careers. With this purpose, semi-structured interviews were conducted. Findings revealed several issues that teachers face in four dimensions: mathematical knowledge for teaching, classroom management and organization, assessment of students' learning, and the context of teaching. Also, teachers' prior beliefs and expectations showed a general lack of awareness, oversimplified beliefs, and unrealistic optimism about the teaching profession. The findings of this study have shown a deficiency in teacher-education programs in terms of not providing pre-service teachers with enough knowledge of the challenges they may encounter, naturally resulting in the inability to reflect on the various reasons for those challenges and how all four aspects of teaching interact with one another. Regarding the findings, teacher education policies should be refined to help pre-service teachers to develop a more realistic and holistic view of teaching mathematics.
\end{abstract}

\section{Keywords}

Beginning teachers $\bullet$ Mathematics teacher education $\bullet$ Mathematical knowledge for teaching $\bullet$ Beliefs and expectations $\bullet$ Challenges

\footnotetext{
1 Correspondence to: Özge Keskin, Graduate School of Education, Bilkent University, Ankara 06800 Turkey. Email: kabakci.ozge@gmail.com

2 BAUSTEM, Bahçeşehir University, İstanbul 34353 Turkey. Email: sencercorlu@gmail.com

3 Graduate School of Education, Bilkent University, Ankara 06800 Turkey. Email: apayas@bilkent.edu.tr

Citation: Keskin, Ö., Çorlu, M. S., \& Ayas, A. (2018). Voicing mathematics teachers: A holistic overview of their early career challenges. Educational Sciences: Theory \& Practice, 16, 331-371. http://dx.doi.org/10.12738/estp.2018.2.0025
} 
It is widely believed that student success in school is related to the quality and effectiveness of teaching. In fact, educating teachers for high-quality teaching is the primary goal of all teacher education programs. It is believed that high-quality teaching will ensure student success at school and will consequently help students be successful in later stages of their lives. Although the quality of teaching is strongly related to initial teacher education, the experiences of beginning teachers after their initial teaching training stand as one of the important factors affecting teachers' performance throughout their career (Darling-Hammond, 1999; Hill, Rowan, \& Ball, 2005; Wayne \& Youngs, 2003). From this perspective, beginning teachers' experiences after their initial education at universities are critical for a successful career.

The literature on challenges that beginning teachers face showed that they had to cope with many difficulties at the same time (Fantilli \& McDougall, 2009). Veenman's (1984) international review of perceived problems among beginning teachers comprised findings that included challenges in managing disruptive behavior in the classroom and overall classroom management, motivating students, dealing with individual differences, assessing students' work and relationships with parents. Related to these difficulties, the researcher indicated that a consistency in these problems should be expected across both time and differently structured education systems. Lack of personal and emotional support, obtaining instructional resources and materials, planning and managing instruction were some of other findings when novice teachers' early career challenges were examined (Gordon \& Maxey, 2000).

Moreover, similar studies conducted on novice teachers' early career experiences in Turkey revealed results consistent with the studies conducted elsewhere. These studies revealed that classroom management was one of the areas that challenged novice teachers (Akın, Yıldırım, \& Goodwin, 2016; Gergin, 2010; Kozikoğlu, 2016; Taneri \& Ok, 2014). For example, a comprehensive research that investigated the induction period of 465 novice teachers from randomly selected 8 provinces of Turkey illustrated that the most frequently reported difficulties were heavy workload, low social status and perceived identity, problems in relationships with the school principals and inspectors, and problems in classroom management in that order (Öztürk \& Yıldırım, 2013). In another study, it was found that novice teachers were challenged because of insufficient physical structure and facilities of the schools that they work in and classroom management. In addition, it was also highlighted that novice teachers had to cope with a heavy workload (Kozikoğlu, 2016). Studies conducted on the challenges that mathematics teachers face in Turkey were very limited. In addition to the complications that were found in other studies like classroom management or time management, challenges peculiar to a middle school novice mathematics teacher originated from the national curriculum context and its effect on teaching practices (Haser, 2010). Lack of content and pedagogical content knowledge, difficulty in implementing student- 
centered teaching practices and difficulty in use of alternative teaching methods were found to be challenges the beginning middle school mathematics teaching had to deal with (Yanik, Bağdat, Gelici, \& Taştepe, 2016).

Taking all this into account, investigating the differences between expert and novice teachers has been a popular area of inquiry in order to understand novice teachers' practices in depth. For example, in the extensive review of Kagan (1992a), it was stated that novice teachers were much more focused on classroom control than on preparing lesson plans that foster learning. As a matter of fact, compared to experienced and expert teachers, novice teachers were found to be less successful in responding properly to unexpected student responses. Instead, novice teachers were very sensitive to disruptive student behavior (Fogarty, Wang, \& Creek, 1982). Another problem was that those novice teachers consumed more time and ended up with less efficient plans, as they were less focused on reflecting on lessons compared to expert teachers and the differences between novice and expert teachers were attributed to novice teachers' cognitive schema about teaching, which were superficial, less interconnected and less complex (Borko \& Livingston, 1989). Unlike the novice teachers, expert teachers have had a more thorough teaching schema over the years. While expert teachers took students' perspectives and cognitive abilities into account during the preparation of lesson plans, beginning teachers were more likely to prepare structured lesson plans and could not adapt their lessons to students' needs (Westerman, 1991).

It is acknowledged that all these troubles have reflected negatively on many different aspects of the work of beginning teachers. To begin with challenges that teachers faced during early career led to high attrition rates in many countries, including the U.S, Australia, England, and China (Department for Education and Skills, 2005; National Commission on Teaching and America's Future, 2003). However, attrition was not a major problem in Turkey as they chose to stay in the teaching pipeline with high burnout rates. Furthermore, the burnout syndrome experienced by novice teachers was mentioned in many studies (e.g. Fisher, 2011; Gavish \& Friedman, 2010). Lack of appreciation and professional recognition from students and other stakeholders, and lack of support from colleagues were found to be the factors that contribute to burnout of teachers in their early careers (Gavish \& Friedman, 2010). For instance in Turkey, beginning teachers faced burnout due to several reasons, including lack of positive feedback from students and lack of support from colleagues (Bümen, 2010; Gündüz, 2005; Tümkaya, 1996). Third, the quality of instruction and classroom learning environment were additional areas of concern in many Organization for Economic Co-operation and Development (OECD) countries, including Turkey. According to the results of Teaching and Learning International Survey (TALIS) 2008, beginning teachers seemed to have less than 2 years of teaching experience, and they reported lower levels of positive classroom climate, combined with greater losses of time during instruction when compared to experienced teachers (OECD, 2009). 
Besides short-term effects of early career issues like attrition and burn out, it should be acknowledged that these challenges would have effects in the long run. As the early experiences of teachers shape their development, these challenges not only influence their effectiveness in their initial years but also their effectiveness throughout their careers (Gordon, Kane, \& Stager, 2006). The problems that beginning teachers face in the classroom during initial years of teaching makes stakeholders question the effectiveness of teacher education programs in Turkey (Çakıroğlu \& Çakıroğlu, 2003). After the year 1997, the Higher Education Council (HEC) in Turkey increased the faculty-school partnership including school experience and teaching practice courses. However, the amount of time spent in schools and number of lessons taught by pre-service teachers were not adequate (Kocadere \& Aşkar, 2013). Research conducted on the challenges novice teachers faced in Turkey found inadequate preparation of pre-service teachers in terms of quality and quantity of school experiences that the novices had before entering the profession (Kozikoğlu, 2016). Özcan (2012) offered a two-year teacher preparation program together with a master's degree for carefully selected applicants who already had a bachelor's degree. In Turkey, the quantity of such programs is very limited. The learning-to-teach experiences of teachers who have graduated from a practice-based program accompanied with substantial theoretical courses would give insights to shape both teacher education courses and teacher education policies.

\section{Theoretical Framework}

The learning-to-teach process enlightens educational research on teachers' development and gives insights into the growth of teacher education practices as well as teacher development policies. Yet teacher's learning and development remain very complex domains. Hence, there have been several attempts to explain this complicated and never-ending path including the longitudinal studies that shed light onto learningto-teach processes (Bullough, 1989; Clift \& Brady, 2005; Fuller and Bown, 1975; Hollingsworth, 1989; Levin, 2003; Pigge \& Marso, 1997). Various theories tried to explain teacher learning and many theories divided teachers' careers into phases by taking a developmental or psychological stance (Levin, 2003). In their longitudinal study, Fuller and Bown (1975) explained this process in terms of three concerns of novice teacher: survival concerns, teaching situation concerns, and pupil concerns. Similar to Fuller and Bown (1975), Ryan (1986) identified four developmental stages that novice teachers went through. These stages have been identified as fantasy, reality, master of the craft, and impact. Both pupil concerns and impact stage were noticed to be more complicated in terms of teachers' thinking. Another model with a cognitive psychology approach was offered by Hollingsworth (1989) as the model of complexity reduction in order to explain learning to teach processes of beginning teachers. Due to the complexity of the nature of learning to teach and because of the selective nature of attentional capacity of a human being (Bransford, 1979), teachers 
tend to focus on specific issues in the complexity of classroom issues. This focus of attention varies from teacher to teacher. Thus, beginning teacher learning has been examined in three dimensions: the role of prior beliefs, areas of cognitive attention, and depth of cognitive processing.

The importance of prior beliefs was mentioned in many studies that investigate the learning of a teacher (Fuller and Bown, 1975; Kagan, 1992b; Levin, 2003; Pajares, 1992; Ryan, 1986). Beliefs and conceptions about teaching are lenses that influence the way teachers see problems and dilemmas in classroom and consequently affect the way they take action (Richardson, 1996). Belief systems in general can be thought as a continuum that involves beliefs from central to peripheral (Rokeach, 1968). Core beliefs are central beliefs, which are resistant to change, and the more central the belief is, the more likely a teacher act on these beliefs whenever a problematic and perplexing situation arises (Pajares, 1992). Beliefs about teaching include teachers' expectations of teaching profession and they play an important role in the beginning teachers' experiencing reality shocks (DeRosa, 2016). It was revealed that pre-service teachers start the profession with a tendency to believe that they would have less difficulty compared to whatever a beginning teacher could possibly face (Weinstein, 1988). In addition, mathematics teachers' beliefs on the nature of mathematical knowledge and mathematics teaching were also found to be determining factors in teachers' teaching practices (Baydar \& Bulut, 2002; Dede \& Karakuş, 2014; Haser \& Star, 2009; Raymond, 1997; Thompson, 1984). Epistemological beliefs about mathematics, in other words, beliefs about nature of mathematical knowledge are associated with instructional choices. Epistemological beliefs related to mathematics vary from static to dynamic. In other words, the beliefs about nature of mathematical knowledge range from "mathematics consisting of isolated facts and rules" to "mathematical knowledge being driven from problems and is continually expanding due to human enquiry." (Ernest, 1989). These beliefs were associated with teachers' orientation about learning and teaching i.e. constructivist and transmissive/behaviorist theories of learning (Voss, Kleickman, Kunter, \& Hachfeld, 2013)

According to Hollingsworth (1989) beliefs affected the primary areas of focus and functioned as filters for teachers' learning both in pre-service and in-service learning to teach. There were three main foci of attention; (i) management and organization, (ii) subject matter/pedagogy, and (iii) students' learning from academic tasks (Lidstone \& Hollingsworth, 1992). Overall, attention to students' learning is claimed to require an integration of management/organization and subject matter/ pedagogy. However, to achieve integration one must first routinize management and subject matter/pedagogy knowledge separately. Besides these, teacher learning was affected by the context that the teachers found themselves in (Levin, 2003). However, contextual factors should be taken into account while investigating the process in 
which beginning teachers learn to teach. Although the context was not an area of cognitive focus according to Lidstone and Hollingsworth (1992), the influence of external factors and context had been found to be affect teachers' learning in the study of Clarke and Hollingsworth (2002).

Although teachers' challenges can show similarities across disciplines, examining secondary school mathematics teachers' problems could be better analyzed with a framework specific to the knowledge of mathematics teachers. Ball, Thames and Phelps (2008) proposed Mathematical Knowledge for Teaching (MKT) framework based on Schulman's (1986) categories of knowledge of teachers, especially on pedagogical content knowledge as MKT served more integrated and complex framework specific to mathematics teaching. MKT is composed of two main parts; subject matter knowledge (SMK) and pedagogical content knowledge (PCK). In Figure 1, it can be seen that each main part is composed of three subunits. (SMK) consists of common content knowledge, specialized content knowledge, and horizon content knowledge. PCK, on the other hand, is composed of knowledge of content and students, knowledge of content and curriculum, and of content and teaching.

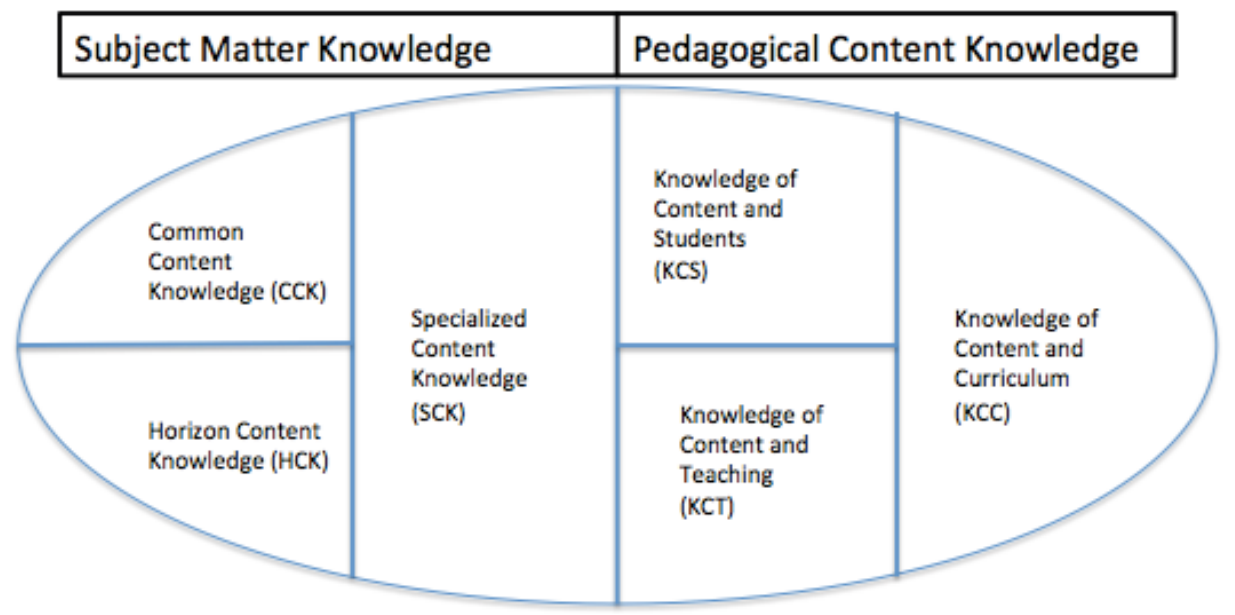

Figure 1. Model of Mathematical Knowledge for Teaching (Ball et al., 2008).

Common Content Knowledge (CCK) is defined as mathematical knowledge and skills used in settings other than teaching; it is considered to be the problematic part of the MKT framework for secondary school mathematics teachers. The CCK differs for secondary school mathematics teachers who had a mathematics education in their undergraduate study. However, there are studies that use MKT framework to assess mathematical knowledge of secondary school mathematics teachers (e.g. Khasaka \& Berger, 2016). In this case, CCK will be taken for this study as knowledge of 
mathematics held in common with professionals in other mathematically intensive fields. Bearing in mind that this knowledge is not unique to teaching, teaching mathematics requires knowing how to solve a particular mathematics problem or knowing how to carry out a procedure as well as knowing the definition of a concept. However, specialized content knowledge (SCK) is the mathematical knowledge and skills used by teachers in their work but not generally possessed by well-educated adults, such as how to accurately represent mathematical ideas, provide mathematical explanations for common rules and procedures, and examine and understand unusual solution methods to problems (Hill et al., 2005). In addition, horizon knowledge (HCK) is an awareness of how mathematical topics are related over the span of mathematics included in the curriculum. As for the pedagogical content knowledge subunits, knowledge of content and students (KCS) includes cognizance of both mathematics and students. In other words, it is the knowledge of both content and what students know about the content in addition to how students know and learn that content. Knowledge of content and teaching (KCT) combines the knowledge of mathematics and the knowledge of teaching. Finally, knowledge of content and curriculum (KCC) is about the identification of the purposes of teaching mathematics and relationships in the curriculum (Kim, 2013).

The importance of examining challenge-based experiences was recognized since teachers began to develop more complex schema about teaching when they encountered problems and dilemmas in teaching, and when they percieved the mismatch between their existing schema about teaching and what they had encountered in practice (Levin, 2003). This study, focusing on the challenges, aimed to examine participants' learning to teach experiences. The research is limited to early career experiences of mathematics teachers. Regarding the gap in the literature; the purpose of this study is to reveal the challenges that secondary school mathematics teachers who are graduates of an alternative teacher preparation program face early in their career. Aligned with the purpose, the main research question of this study is:

- What are the challenges that mathematics teachers face during the early career stage?

In relation and as an extension of this question, the following research questions are also focus of this research;

- What are the prior beliefs and expectations of the mathematics teachers on the dimensions of teaching that they were challenged by in their early career?

-To what extent did they integrate different dimensions of teaching while reflecting on the reasons for those challenges? 


\section{Method}

\section{Research Design}

The methodology of this research was exploratory and descriptive with the aim of reaching an in-depth understanding of a group of mathematics teachers' experiences in their early careers. This endeavor of gaining an in depth understanding brings us to the naturalistic paradigm of inquiry that is characterized as an interpretive, naturalistic approach to the world, studying things in their natural setting, trying to make sense of, interpreting the phenomena regarding the insight that people bring (Denzin \& Lincoln, 2005).

\section{Participants and Context}

Purposive sampling was utilized under the umbrella of maximum variation sampling in which people could give rich information to document unique variations that emerged in adapting to different conditions (Lincoln \& Guba, 1985). Participants were purposefully chosen in order to enrich the inquiry. The purposive sample of participants was determined by the criteria that participants would differ in terms of characteristics of the participant such as year of experience, gender and potential to give rich information about the challenges that they experienced openheartedly. In addition to personal characteristics, varieties in school contexts the participants' work were also considered. Thus, the schools varied in terms of the city located, size, student profile and being well-established or newly established.

All of the participants were graduates of the same program offering a teaching certificate at the graduate level. All participants were working as full-time mathematics teachers in private schools. Detailed information is given in Table 1. Participants were named $\mathrm{T}$ followed by a number for anonymity. The vast majority of the program had female graduates and consistent with this fact that there was only one male teacher in the sample. In Table 1, it was shown in which grade levels they had experince. All of the participants except one of them worked in schools, which offer International Baccalaureate Diploma Program (IBDP) in addition to the national curriculum. T1, $\mathrm{T} 4$, and $\mathrm{T} 10$ had a mentor during their first years. T1 and T10 had an induction year, during which they only observed the lessons of experienced teachers or co-taught. The rest of the participants had the same responsibilities of an experienced teacher in their first years. They had 20-24 hours of teaching in a week. However, T2 had 30 hours of teaching per week in her first years. The schools that participants worked or are currently working are all located in metropolitan cities of Turkey. 
Table 1

\begin{tabular}{ccccc}
\multicolumn{5}{l}{ Information About Participants } \\
\hline Participants & Year of Teaching & Number of schools worked & Grade levels taught & Gender \\
\hline T1 & 3 & 3 & Secondary (9-10-11) & F \\
T2 & 3 & 2 & Secondary (all) & F \\
T3 & 3 & 2 & Secondary (9-10-11) & F \\
T4 & 5 & 2 & Secondary (all) & F \\
T5 & 8 & 3 & Middle \& Secondary (all) & F \\
T6 & 9 & 2 & Secondary (all) & F \\
T7 & 2 & 1 & Secondary (9-10) & F \\
T8 & 3 & 1 & Secondary (all) & M \\
T9 & 3 & 1 & Secondary (all) & F \\
T10 & 1 & 1 & Secondary (9-10-11) & F \\
\hline
\end{tabular}

Teacher education context of the participants. All 10 participants were graduates of the same master's degree program offering a teaching certificate. For the rest of the paper, this master's degree program will be referred as "the program". Opened in 2000, the program has produced more than 300 graduates. Before 2010, it was a two-year non-thesis master's program accepting students having degrees in biology, mathematics, Turkish literature and language, history, and English. After 2010, the program became a master's degree program with a thesis in Curriculum and Instruction with a teaching certificate. This program differs from other graduate teacher education programs and other teacher preparation faculties in many ways. One of them is the opportunity of having teaching experience in a variety of schools, together with the longer times spent in these schools compared to any teacher education program in Turkey. During the first semester of the second year, the preservice teacher spends six whole weeks in a school. Partner schools are in Ankara, İstanbul, and İzmir, as well as in the UK. Until 2010, student teachers spent two months in the US. From 2010, student teachers have undertaken overseas experience in England, attending classes at the University of Cambridge in the Postgraduate Certificate in Education program, and have acquired experience in five different prestigious schools. In addition to these, graduates of the program have begun to attain an International Baccalaureate Teaching Certificate after 2011.

One of the most prominent parts of the program is the teaching practice in the third semester. During the teaching practice, student teachers spend six whole weeks in the school to which they are assigned. Unlike the previous school experience courses, they do more teaching in addition to observing different teachers. Throughout these six weeks, they teach approximately 30 periods and participate in departmental studies. During this extensive teaching practice period and while being exposed to a plethora of school experiences during the first and second semester of their program, pre-service teachers additionally have to prepare detailed lesson plans for each lesson they teach. Mentors or supervisors give both written and oral feedback. Moreover, 
pre-service teachers evaluate each lesson with a self-evaluation form, which gives them an opportunity to reflect on their lesson. Compared to other pre-service teacher education programs, the graduates have more chances to experience teaching before embarking on their teaching career.

\section{Data Collection Process}

Potential participants were invited to participate in the study via phone or e-mail. 10 people responded to the invitation. Due to the purposes of the study, semistructured interviews were held with participants in order to get rich information regarding the fact that the interviewee's own definitions, wording, and perceptions are central to qualitative research. The characteristics of semi-structured interviews allowed the participants to answer the questions in their own way using their own words (Matthews \& Ross, 2010). An interview protocol was created. The expert view was taken for interview questions and a pilot interview was conducted in order to ascertain if there was a need for further refinement that would make the participants understand the questions better. Each participant was asked to answer questions regarding the years of teaching that they did feel novice. However more or less these early career years corresponded to first three years of teaching and that is consistent with the literature (Veenman, 1984). Interviews were carried out face to face and lasted between 90 and 120 minutes.

Sample questions from the interview protocol are shared below:

i. Why did you choose to teach as a profession?

ii. What were your expectations from the profession before and after the program?

iii. To what extent did your expectations match with the realities of teaching?

iv. What kind of problems and challenges did you face within your first years of teaching? (Sub-questions followed in order to dig into the problems that might have been faced related to different dimensions of teaching)

v. What were the reasons of the challenges that you faced within your first years of teaching?

\section{Data Analysis}

All audio data were transcribed word by word. The researcher read all verbatim transcripts carefully. Data were analyzed using the constant comparative method (Lincoln \& Guba, 1985). The constant comparative method (Lincoln \& Guba, 1985) was utilized in order to gradually form categories from the data by i) comparing incidents applicable to each category, ii) integrating categories and their properties, 
iii) delimiting the theory, and iv) writing the theory (Glaser \& Strauss, 1967). Content analysis requires unitizing the data, which means finding the smallest unit of meaningful data (a word, a phrase, a sentence or a paragraph) according to the area of research. After identifying these units in the data, each unit was assigned to a category. The researcher used software for the mechanical processing of data such as organizing, modifying and retrieving the data. It is still the researcher's skill (not the software) to interpret the data (as cited in Lincoln \& Guba, 1985). In order to analyze the data, the researcher read the interview transcripts several times and unitized the data according to four dimensions which were challenges, beliefs, expectations, and reasons. Then, these were grouped under categories of the main foci of attention of teachers in terms of challenges utilizing the theoretical framework. While creating categories, main foci of attention in the studies of Hollingsworth and Lidstone (1992) and Clarke and Hollingsworth (2002) were considered. Subject matter and pedagogy category was replaced with Mathematical Knowledge for Teaching (Ballet et al., 2008) in order to provide more specific information related to the challenges in teaching mathematics.

\section{Trustworthiness}

Credibility. (Operational word for internal validity in naturalistic paradigm) One of the ways to ensure credibility in qualitative research is prolonged engagement, which can be defined as spending adequate time in order to achieve the goals of the research such as learning the culture, testing the possible misinformation given by respondents or researcher, and building trust (Lincoln \& Guba, 1985). Through being a graduate of the same program as the researcher, working in a private school, having knowledge of the culture of the schools that most of the participants worked, knowing participants in person as a colleague, friend or mentor, a prolonged engagement was established. In this stage, the researcher's role was especially critical since participants were asked to share problems and challenges that they faced in their early career. The researcher needed to make them feel comfortable to talk and give in-depth descriptions of their experiences.

Building trust was an important issue in establishing the credibility of qualitative data. The importance of the input provided by the participants to the inquiry process and anonymity of the participants were emphasized at the beginning of the study (Lincoln \& Guba, 1985).

\section{Results}

The challenges that participants focused on in their early career were coded under four major categories: mathematics knowledge for teaching, management, and organization, assessment of student learning and context as indicated in Table 2. Participants' prior beliefs and expectations about the challenges and perceived 
reasons for these challenges were shared under each category. The prior beliefs and expectations that participants held about teaching had shown signs of lack of awareness of possible challenges, oversimplifying teaching and unrealistic optimism about the profession. In addition to the prior beliefs and expectations, participants shared perceived reasons for experiencing the challenges. Through reflecting on the challenges, the source of the challenge in one category was attributed to the challenges experienced in other categories.

Table 2

Challenges in Four Main Categories

\begin{tabular}{llll}
\hline $\begin{array}{l}\text { Mathematical Knowledge } \\
\text { for Teaching }\end{array}$ & $\begin{array}{l}\text { Classroom Management and } \\
\text { Organization }\end{array}$ & $\begin{array}{l}\text { Assessment of students' } \\
\text { learning }\end{array}$ & Context \\
\hline Lack of subject matter & $\begin{array}{l}\text { Difficulty in maintaining } \\
\text { knowledge }\end{array}$ & $\begin{array}{l}\text { Failure of majority of the } \\
\text { students in the exams }\end{array}$ & Overwhelming \\
Lack of pedagogical & Students' misbehaviors & Difficulties in keeping track and & National \\
content knowledge & Students' lack of motivation & recording students' progress & Curriculum Load \\
& Lack of lesson planning and & Challenges in giving & Lack of support \\
& preparation & performance grades & from colleagues \\
\hline
\end{tabular}

\section{Mathematical Knowledge for Teaching}

All participants mentioned lack of sufficient mathematical knowledge for teaching. Most of the participants affirmed concerns related to their lack of subject matter knowledge before they have started their career. Participants were aware that they had to work hard in order to recall some topics in secondary school mathematics during their initial years. As a matter of fact, their concerns related with teaching mathematics before they have started their career was limited with recalling the rules and concepts in secondary school curriculum or just being able to solve the questions that they would encounter. As T2 expressed, the prior beliefs that participants hold about subject matter knowledge appeared to be related to mostly just common content knowledge.

I used to believe that my content knowledge was sufficient for teaching. Of course, there were topics that I had concerns, but I realized that even for the ones I thought that I was competent, there were lots of missing parts. Without being aware of my inadequate knowledge related to where does a rule come from, I used to see myself sufficient in terms of content knowledge. However, I saw that there are many things that a student can question.

As could be understood from T2's expressions, mathematics teachers needed to have a specialized type of mathematical knowledge. Teachers' specialized content knowledge set them apart from other people who had knowledge of secondary school mathematics and it consisted of answering "why" questions of students, being able to question students' conceptual understanding or being able to explain the reasons behind rules, formulae, and theorems. It was revealed that absence of specialized content knowledge challenged them when students questioned the concepts behind the given rules. They knew the rules and procedures in a topic but the reasons behind the rules were missing. To illustrate an example, T6 said: 
Teaching taking the square root of a number is easy when you just gave the definition or rule to the students and expect them to apply it. However, one of the students questioned me why we can write as . I had never questioned it before... There are lots of questions related to infinity. What does infinity mean, what does it mean to approach infinity or not reaching infinity? Similarly, they don't understand the difference between indeterminate and undefined. We have to think about it before we teach.

Besides shortage of specialized content knowledge, participants shared challenges related to teaching the content that they were never taught during their schooling. For example, participants mostly worked in IBDP schools and they were responsible for teaching statistics that they never undertook before. IBDP mathematics curriculum involved probability distributions and least square regression as well as descriptive statistics. Therefore some participants felt insecure about teaching statistics. The following excerpt from T8 stands as an example:

Statistics... No matter how much we (teachers) study, we cannot internalize since we did not learn statistics before. I felt this lack of internalizing (in teaching statistics). I got prepared to the lesson by studying the books and materials. However, there were questions beyond the books; the questions that arouse in a students' mind. I was not prepared for this and the answers were not written in the books. I was anxious and asking myself, how could I answer? Where will I find the answer?

Apart from IBDP mathematics curriculum, national curriculum and national exams had also put a pressure on how to handle the deficiency of subject matter knowledge. Students expected their teachers to solve the university preparation test questions and not being able to solve these questions quickly caused a stress in initial years, as T6 expressed:

There were problems with my content knowledge. I was teaching 12th grades in my first year of teaching and I forgot the practical ways to solve the test questions. I was not as practical as I was in my high school years. That's why, in my first year, I had a need to study a lot at.

Besides the topics or questions that participants felt anxious about, they also had challenges with knowledge at the mathematical horizon. Participants who felt ready to teach the topics in the levels that they were assigned to teach, realized that students' curiosity about the extension of the topic could be a challenge for them. For example, T7 who was responsible for only teaching $9^{\text {th }}$ grade had been challenged with the students' questions requiring extending the knowledge. One of the reasons for the problems related to knowledge at the mathematical horizon were asserted by T2 who had not prepared for the whole topic and its extension due to limited preparation time.

For instance, when I was teaching domain of functions I had shown the case of square root that negative values cannot go anywhere. They asked me what could be other situations of being undefined. I said when the denominator is 0 but I had not gone any further... I could not think of trigonometric functions such as tanx or logarithmic functions. I felt panic especially when I was going to teach at that class. It was like a traumatic experience. 
A student asks a question, the answer could be given by considering a further topic in the curriculum. The best thing is to get prepared for the whole topic. We can do it for the first topic early in the year when you have more time to get prepared. However, you cannot catch up afterward. You have no idea what to teach two weeks later.

Lack of subject area knowledge caused some other challenges as participants indicated. Some of the participants attributed the source of challenges in classroom discipline to their lack of subject area knowledge. A relationship between subject area knowledge and maintaining classroom discipline was not evident for participants before they started teaching. However, they realized, after they have started their career, lack of subject matter knowledge damages the authority of the teacher as T1 confined:

Your content knowledge is very important. When you cannot solve even a single question in front of the students, it can damage your authority and discipline. I could not foresee this before I became a teacher.

On the other hand, although T10 also experienced similar challenges in classroom management due to insufficient subject matter knowledge, the response of the participant to this situation differed from other participants:

There were questions that students asked and I could not solve, and this affected my classroom management. Students asked sarcastic questions like "Oh, so, you could not solve?" However, this was not a source of stress for me. I told students that there could be questions that make me struggle and this was normal.

In addition to lack of subject matter knowledge, participants shared problems related to pedagogical content knowledge. One of the major challenges was found to be the lack of knowledge of the content and students. The competencies of mathematics teaching require identifying why students do not understand a particular topic or being aware of potential misunderstanding and misconceptions. Some of the participants realized how pacing and flow of the lesson were connected to their knowledge of content and students. They started to relate mathematical knowledge for teaching to classroom management and organization after they started their teaching career. For example, T2 asserted:

At the moment (during teaching), you may not understand where the student tackled. They may just stick on a meaningless point on the topic, they ask a question, which may confuse other students. Then chaos... There are many factors affecting this situation. However, the most realistic factor is your lack of knowledge of students.

In order to dig into the challenges related to participants' knowledge of content and students, they were asked which topics were most unsettling to teach and which misconceptions students hold. Participants' responses gave clues about the challenges that they had faced not only in the knowledge of content and students. Probability was one of them since there were multiple ways of solving a probability question. 
T7 had expressed how she had got prepared for the lessons after she realized that students' methods would differ from hers:

There are many ways to solve a problem, especially in probability. You might not understand students' method at that moment. After I realized that, I began to get prepared much thoroughly. That's why I tried to think of many methods to solve a probability or combination, permutation problem as much as possible before the lesson.

In addition to probability theory, limits, derivatives and integral in other words calculus topics were also found to be challenging to teach and in first years participants felt ill equipped to teach these topics. Concepts like infinity, undefined and indeterminate terms were also challenging concepts that students ask for further clarification. Trigonometric functions, the concept of absolute value, domain, and range of functions were emphasized as the topics that the participants reported as challenges. To illustrate, T3 had mentioned how teaching absolute value became a problem:

I had really struggled with the absolute value concept. They were very confused how could be possible.

Moreover, knowledge of content and the curriculum was also problematic in the early career of participants as T4 indicated.

I was unable to decide what depth I should introduce the topics. Will I give details in everything I do, to what extent does the curriculum wants us to do? What is the output of an objective? Where are the boundaries?

Knowledge of content and teaching requires adapting teaching to students' levels and their needs. However, coping with diverse needs of students also troubled the participants. T1 related this challenge to the management problems by expressing:

In my class, there are high and low achievers. When I tried to teach low achievers, the rest bored up and start to chat with the others.

Illustrating the challenges that teachers faced in teaching, some student-centered practices were pointed out to be problematic. The program that participants had graduated from designed mathematics teaching method courses around student centered teaching practices. Relating mathematics contents to students' lives or solving problems related to real-life situations, cooperative learning, activities that students explore the content by themselves were frequently mentioned during the program as constructivist approaches to teaching. Accordingly, participants were expected to plan their lessons with a student-centered approach during their internship and they implemented constructivist lesson plans during the program. They were asked questions about their beliefs related to teaching mathematics before they have started their career. Most of the participants shared how their teacher-centered beliefs related to teaching changed during the program. They utilized some of the approaches effectively after they have started to teach, like 
peer learning, pair work or helping students explore the rules themselves. However, they mentioned they did not continue to teach according to some of the constructivist approaches after they started their career. In this regard, T2 expressed that:

After I graduated, I was thinking that I would be a different teacher (from her own teachers). I would teach with constructivist approaches; for example, group activities, performance tasks... You can not do it with every class or even you do it, you can not get the same response. You became demotivated. You fail because of the time limitations, process and with the student profile. Hence, my expectations did not match with the realities of teaching.

Linked to what T2 expressed, there were participants who tended to stop doing what they had found to be effective when they were pre-service teachers. However, participants did not seem to reflect deeply on the reasons for the failure. They attributed the source of the failure to students' lack of motivation and behaviors. They seemed not to question if the activity was appropriate or not. In the end, the theory was found to be inapplicable in practice, as it could be understood in T10 statements:

I had conducted group activity only once. I had a plan beforehand. I arranged the groups. I gave directions. Although I carefully thought about every single detail, it did not work. I swore I would not do it again. They did not pay any attention except a few students. They did not learn what I intended to teach.

Like cooperative learning, connecting topics to students' lives and the importance of relating topics to real-life situations for meaningful learning and for the motivation of students were frequently mentioned during the program. Participant's beliefs about connecting topics to real life before their teaching career, and how it changed during practice needed attention. T3 expressed that giving real-life examples was seemed to be something that could be dispensable for because of some contextual reasons:

I was thinking like it would be easy to give real-life examples on each topic before I started teaching. However, during rush to cover up the curriculum all the time, I could not focus to do this, I could do it only at the beginning of each topic. Most of the time, I don't give the effort to do this.

In addition to these examples, it was noticed that while expressing their ideas about teaching, they used words "to give" and "to take" for teaching and learning. This language reflected participants view about the role of the teacher, as the giver of the information, and the student as the receiver, which indicated a transmissive theory of learning. To illustrate, $\mathrm{T} 1$ said:

We have been taught about learning disabilities. However, experiencing it yourself is different from knowing these. You give; students don't take. It is very different.

To conclude, participants experienced challenges mostly in specialized content knowledge, knowledge of students and content and student-centered teaching practices. Expectations about these challenges revealed a lack of awareness about 
these knowledge bases. Although participants seemed to have beliefs that studentcentered teaching should take place in teaching, they tended to be more teachercentered in their early career. In addition, it was revealed that they started to realize how different dimensions of teaching were integrated by relating their lack of mathematical knowledge for teaching to classroom management problems.

\section{Classroom Management and Organization}

All of the participants expressed that they faced classroom management problems in their early career. Some of the participants said that challenges in classroom management were the most unexpected and the most demanding. These participants stated that they had no concerns about classroom management issues before they entered the job. Participants had observed classes with discipline problems during their internship and they themselves experienced minor classroom management problems in their student teaching. However, they might not have reflected deeply on these and did not develop constructive strategy about what they would do vis-à-vis of classroom management in their real teaching career.

During the program, participants perceived classroom management as it was composed of only applying some specific strategies. Reducing classroom management to some strategies or tactics instigated a reality shock. In general, teachers' simplifications of teaching as a profession caused the reality shock. An example of oversimplifying the process of classroom management was indicated by $\mathrm{T} 7$ :

...We thought that if you knew the rules to manage a classroom, you could just do it. In fact, it is not that easy...

The data revealed how these oversimplified beliefs about teaching profession and classroom management specifically could be miscontrued. It was noticed that teachers' perceptions and expectations about teaching were shaped by both the courses in the program and the experiences in practice schools as well as their construction of teaching schema as they were pupils. Participants expected that real teaching would resemble what they had experienced during the internship. However, during the internship, while they were teaching, they had a mentor who was continually observing and helping them. To illustrate, reflecting on the internship experience, T4 and $\mathrm{T} 2$ expressed:

I have never experienced classroom management problem when I was a pre-service teacher. Maybe the presence of the mentor in the class was a factor. There was no moment that I needed to warn the students.

I didn't expect to shout. I did not shout at all during the internship. Since I did not observe horrible classes, I haven't seen teachers shouting at students. 
Unfortunately, expectations were not met. Their career started with many challenges related to classroom management. Major problems that they faced would be listed as the distractive behaviors of students, noise in the classroom, students' disrespectful behaviors towards the teachers and use of slang words among themselves. Students' disrespectful behaviors were again shocking for some of the participants. Participants seemed to have incomplete and unrealistic beliefs about students' attitudes. Quarreling with students and shouting were expressed as their dealing mechanism in the early career. The precarious part of the classroom discipline made participants feel helpless and uncomfortable, as T3 and T2 explained:

I had problems dealing with behavioral problems in the class. On many occasions, I have encountered attitudes that I never thought I would face... It was really disappointing feeling incapable managing the class.

I turned out to be a person who usually shouts at students in order to control them. It did not work.

When reasons of classroom management problems were questioned, one of the main factors expressed was students' inattentiveness to mathematics lessons. Actually, the disparity between expectations and realities related to students' attitudes towards mathematics were shocking for participants. They also realized how the lack of motivation of students could affect their own motivation. As T7 expressed:

I would never think that I would be worthless for students. I sometimes feel like this. They have no concern learning something from you. They just want to come and sleep. I had never thought that type of student would demotivate me to this extent.

When it was questioned why demotivated students were so shocking for the participants, it was revealed that the schema they shaped during the program and the schema that they had as pupils again came onto the scene. T6 and T2 addressed the reasons as:

I have been taught to teach to the students who are willing to learn; I realized that I haven't known how to teach to the ones who do not want to learn. This was a huge shock.

During the program, I have thought about students would be like me when I was a pupil.

When they were asked if they could observe a pattern in the situations in which they had management problems, most of the participants expressed that whenever they did not feel ready for the lesson, there occurred classroom management problems. It might be very trivial for teacher educators and experienced teachers. However, it was noteworthy that participants realized this not during their training but in their early career. According to participants, teachers' inadequate lesson planning and consequent lack of confidence in teaching a particular topic reflected negatively in their classroom management. Participants also begun to recognize a link between mathematical knowledge for teaching and classroom management more lucidly after they had started their teaching career. As T2 and T7 addressed: 
Lesson planning affects your authority... If you feel secure (in terms of planning), If you are self-aware, you hold your ground before the students, your classroom management works better. But your schedule should be set in a way that enables you to prepare better. (During the program, relationship between lesson planning and classroom management) were not considered.

I knew that my content knowledge, pedagogic content knowledge or lesson planning would reflect in classroom management but I was not expecting that much of an effect.

Lesson planning was mentioned as a possible cause for management problems. In order to have a better understanding of participants' lesson planning, they were asked more questions about planning. It was revealed that none of them had a structured lesson plan as they had devised during the program. They had to prepare lesson plans during the program, which included the objectives of the lesson, and mainly listed the teacher and student activities with an estimated timing during the program. In their early career, there was no obligation related to written lesson plans. They mostly stated that they had a plan in their mind. If there were ready to use materials; books or lesson notes provided by the department, they studied to retrieve the content from those, solved the problems that they assigned as homework. If they were not provided any notes, they tried to prepare lesson notes from different sources. A few participants suggested that they were imagining possible questions that students might ask during their preparation. During their internships, they mainly tried to include activities, which were student-centered, included an engaging introduction to the lesson. Some of the teachers expressed that they tried to continue this at the beginning but they had less energy to search for engaging activities after the workload increased.

Contextual factors were also found to be among thereasons of classroom discipline problems. The timing of the lesson, especially being one of the last periods of the day, was conveyed as one of the factors that affect classroom discipline since students become tired and demotivated to learn. This issue was again an unexpected side of teaching. For example, T3 and T10 addressed:

In the last period I could not manage to keep students on task, maybe it's just me, I don't know.

The size of the class does not matter. Students' attitudes change depending on the time of lessons. Sometimes, in the last periods, students want us just to stop. I was not expecting this.

Although participants did not mention many challenges in the relationship with the administration, a few had pointed the attitudes of administrators as another contextual factor affecting the discipline of the classroom. More specifically, the lack of support from the administration when discipline problems arouse was expressed. Inconsistency between teachers' and administrators' attitudes towards students damaged participants' authority as T3 and T5 had expressed:

In one of the lessons, I warned the students quite a few times, and in the end, I said 'Don't you understand, are you stupid or what?'. I know that I should not have said it. The student told 
it to the assistant principal. The assistant principal told me that the student did not attend my classes because of what I had told him. The student was a problematic one, he and his friends don't attend most of the lessons, and vice principal defends them.

You take the students' phone when he/she plays with it during the class, you don't want to give it back in order to punish him/her or to change his/her behavior, but when the administration doesn't support you in this sense, you lose authority.

Moreover, the ages of the students were found to be a factor affecting classroom management. Besides, the age of the participants was another concern. Parents' reactions also stiffed their concerns in their early career. T2 and T3 addressed these issues with these expressions:

We are too young (during the first few years), the age difference is not much... $12^{\text {th }}$ grades wear down more, and they are more challenging.

When you are young, parents automatically perceive you as inexperienced. At the meetings, they always point out how young we are.

One of the contextual factors that participants addressed was that students had access to learning mathematics from different sources rather than school. Most of the students' had private tutoring or attended university preparation courses. This had also challenged participants in terms of classroom discipline since they were not the only source of information. However, this had also shown sign of teacher's point of view about teaching; teacher as the source of information in teaching and learning. To illustrate, T3 expressed:

Students who have private tutors or the ones at the university preparation courses don't pay much attention to my classes. They think that I am no good for them. I can't find solutions to the problems raised by these students.

\section{Assessment of students' learning}

Participants reported challenges related to assessing and evaluating students' learning from academic tasks. Failure of the majority of the students in the exams prepared by the participants, challenges in keeping track and record of students' progress and having difficulties in giving performance grades were mentioned.

To start with, failure of the majority of the classroom in the exam was a problem for most of the participants. This failure triggered the survival concerns of participants and made them question their teaching practices and their prior beliefs about assessment. Apparently, formative assessment tools could not be used effectively to monitor students' learning and adjusting teaching practices accordingly. For example, T4 shared:

...At first, you strongly believe that you taught them. I mean, I emphasized this (issue) several times, they can do it during the class. However, I might give them clues when I ask a 
question, I was not aware of this. When I asked same problems in the quiz or exam, they can't solve. I questioned like "Can't I teach? Am I doing something wrong?

T1 had believed that the failure of majority in the first exams she prepared was related to many difficult items that were chosen for the exam. The criteria that participant set about the exam questions were not seemed to be related to learning objectives.

In the first exam, I had chosen very good questions, which were very tricky or very challenging.

Prior beliefs related to assessing students were the decisive factors in some participants' assessment practices. T2 had a belief that students should be asked questions they were not familiar with from class work. Opposed to what others experienced, T7 had concerns about asking questions in the exams that students were not familiar from classwork. Assessing students turned out to be a pressure for the teacher:

In my first exam, all my students' grades were low. I made a difficult one. I could not arrange the level. I have always thought like the questions in the exam should not be in the style of the ones you solved in the class.

In my first exams, students got very high scores. I made it simple because I was anxious about students' reactions. Especially high achievers want you to teach every single thing, waiting in the wings. They saw a question in a practice book and come to you "you did not teach us this". I could not take the risk... I don't feel any pressure from the administration about students' grades. However, I felt it from students and their parents.

Besides exams, participants were challenged with keeping track and record of students' progress. Checking students' homework was one of these challenges. T3 had mentioned the problem of unorganized checklists that she used and how she conveyed it to a more systematic way over time. T2 asserted the problem of being not clear about the way of keeping track of students' homework and their performances in the classroom, and how this situation caused problems about being fair in giving performance grades.

I was not organized about checking homework and recording these. Now, I am checking homework more systematically. Previously, I was taking notes to pieces of paper, which was not organized. In my second year of teaching, I started to do it with a chart. I continually say students that doing homework is a part of performance grades. In the past, I was not mentioning it often. I was thinking like saying it once at the beginning was enough.

In giving performance grades, a student asks how I gave those grades, comparing his grades with the others'. I looked at my list, I did not know why I put plus on the list, was it for doing homework or for contributing the lesson?.

Moreover, teachers' beliefs about how homework should be used in order to enhance learning contradicted what they had done in practice. Number of students that the participants were responsible for was an important factor in this discrepancy between their beliefs and practice, as T10 pointed out: 
In theory, I know and believe that homework is an important part of education; I knew the importance of giving feedback in order to encourage students to do their homework. However, I saw that it is hard to do it in reality. In my first year of teaching, I had more than 150 students. I was checking their homework and just asked the reasons if they did not do their homework. It was superficial. I don't think that theory is applicable in practice all the time.

Related to these challenges in keeping track and record of students' progress, participants had been burdened with giving performance grades. Performance grades (formerly oral grades) are an important part of evaluation in Turkey's national education system. These grades have the same weight as the exam grades in students' final mathematics grades. Teachers were not given any directives related to these oral grades in the past. Recently, Ministry of National Education (MONE) in Turkey attempted to change it in a way that these grades were supposed to be given according to objective criteria. Performance tasks were a part of those criteria. These were supposed to be class tasks that were constructed to emphasize the real-life applications of mathematics or interdisciplinary nature of mathematics. Participants expressed challenges in preparing and implementing these performance tasks. For example, $\mathrm{T} 2$ had found a challenging real-life problem related with second-degree functions and equations while searching on the internet and thought it would be a good idea to give it as a performance tasks to students. However, it gave her a hard time with the students:

I gave students a performance task, which was a part of the criteria of performance grades. A student preached down me saying "you can't give grades from this, and you did not do something similar in class." I thought they had all the information and skills to solve the question since I taught it second-degree functions and equation. I was wondering to what extent they can use their skills in this topic to solve a real-life problem? I thought they could do it. In fact it was really difficult.

During the program, formative assessment methods were taught and the difference between summative assessments was mentioned. However, some participants believed that students' signs of progress could be evaluated only by the results of summative assessments during their training. To illustrate, T10 mentioned:

I was thinking like, I could give performance grades similar to what they have got from the exams. I was relieving myself by thinking like this before I started to teach. However, It could not be the case in practice.

Actually, in practice, giving performance grades became a very tough and stressful process for some participants as T6 pointed out:

Giving performance grades was very challenging. It even haunted my dreams. Giving homework, recording them, making them a part of the grad; but in the final decision, students' participation in class, behaviors, I was questioning if I am fair. 
On the other hand, teachers who gave performance grades according to criteria that were decided upon collectively by the department reported that giving performance grades was not a big concern. All the criteria were set at the beginning of the semesters and students were informed about the procedures. However, there were teachers who were not happy about pre-set criteria determining performance grades since this situation inhibited their freedom to increase the grades of the students.

\section{Context}

Overwhelming workload and national curriculum load were found as the major contextual challenges. Support that they could have received in these respects but did not was also mentioned as a challenge. Although these were expressed several times as major challenges own, they were also proclaimed to be the reasons of the difficulties in the previous categories; mathematical knowledge for teaching, management and organization and assessing students.

To start with, most of the participants implied that workload was overwhelming especially during the first years. They also perceived overwhelming workload as a reason for other challenges they faced. Out of school time was spent to prepare the lessons and lesson materials as well as to refresh their knowledge about the curriculum. Meetings and administrative reports were also exhausting in addition to the teaching hours. Prior beliefs and expectations related with the workload of teaching profession did not match with the realities of the participants' early careers, as T2 expressed;

...In my first year of teaching, I was teaching 30 hours... There were no materials to use right away and I had to prepare everything on my own. I used to work approximately 6 hours on the computer after school time. This heavy workload demotivated me and even caused a dislike towards this job. I was looking for other jobs at the end of that year. I chose teaching since I don't want to work day and night and since I wanted a social life. However, I don't have a life after all in my first year.

Similar to what T2 experienced, most of the participants had mismatches between their expectations related with the workload of teaching and the reality that they have faced in their early career. Although some of the participants had shared that the internships during the program had given an idea about the workload that a teacher could have, most of the participants stated that there was an unexpected amount of work when they started their teaching career. To illustrate, T4 shared:

I was not expecting to work this much out of the school time and the fact that it (teaching) needs too much preliminary preparation. This is something I realized both during the program and during the early times of my career. One normally assumes things become automatic after some time, however, I realized it was not the case. 
When it was questioned why participants' perception of the teaching profession did not match with reality, it was revealed that the conviction that participants hold about teaching profession seemed to be affected from the public image of teaching as T8 addressed. Moreover, possible deterrents and obstacles were not considered. Instead, mostly idealistic beliefs and expectations about teaching were shared by participants, as T1 asserted:

I believed what had been told to me, that teaching job was easy, teachers worked fewer hours and they worked less compared to another profession. However, it was on the contrary. Six days a week. Even on Sundays, you spend your time preparing for your lessons. You take work home and then you have to work at nights as well. I feel like 24 hours in a day aren't enough to do all my work.

I only wanted to help individuals gain some things and teach them some things. Never thought about the difficulties. Neither did I think about working hours nor the workload. This was a shock at the beginning.

Although the vast majority of the participants perceived workload as unexpected, there were participants who forsaw the intensity of the work-life before entering the profession. T7 even thought that the program was much more demanding in terms of workload compared to a teaching career.

The work pace at the program prepared me to the idea that I have a similar future in the profession. I was not as exhausted after I started teaching compared to the times in the program.

Although the workload was a challenging aspect of teaching in the early career of the teachers, the heaviness seemed to change across schools. In some of the schools, there were no ready to teach materials or have no induction period for teachers. This situation increased some of the participants' workload. The number of colleagues that participants could collaborate with or the number of ready-to-use materials that were prepared by the department affected the workload of participants.

It was not only improving myself academically. Every teacher had to prepare his or her own material and exercises. There was no common source or material among the teachers. When I started at another school, there was less work since the department had more teachers.

Lack of content knowledge was another reason for the long working hours for teachers outside the school. All of the participants have mathematics degrees and they had taken mathematics courses most of which were not directly related to what was taught in the secondary schools' mathematics curriculum. Apparently, they needed to review secondary school mathematics before they started their careers. Although the program provided curriculum review courses, it seemed that they needed to put ib more effort in order to be compatible with the secondary school mathematics curriculum as $\mathrm{T} 1$ mentioned: 
I realized that workload is not only teaching hours. Since I had focused on educational sciences during the program, not on content knowledge, I had to recall, and upgrade my mathematical knowledge after I have started teaching. Most of the days I was studying and solving questions for long hours after the school.

Being a major challenge, overwhelming workload also interfered with teachers' classroom practices. They did not continue to use the methods that they thought were effective during their training. To illustrate, T4 and T2 mentioned:

I used to solve a question related to previous lessons' topics and I tried to give chance to students who were not quite comfortable with the topic. However, consistency is important. I started this way but stopped it after a semester or so... The reason could be because of me, fatigue, quizzes, heavy workload... you give up things.

This much workload had affected my lesson planning. I did not think in depth on my lessons as I used to do in the program. I could not use methods that we had learned during the program effectively.

In addition to an overwhelming workload, the national curriculum in secondary school mathematics in Turkey puts pressure on most of the participants. The main challenge was to cover the entire curriculum in the alloted time given. In addition to curriculum load, lesson losses caused problems in terms of catching up with the annual plan. Teachers faced with many unplanned losses due to weather conditions, school activities, and general exams.

When prior beliefs and expectations about national curriculum were examined, it became clear that participants were mainly concerned about delivering effectively the lesson that they had planned during the internships. They were also reflecting on whether they managed to achieve lesson objectives and covered all that they planned by writing self-evaluations after each lesson. Since they did not have the responsibility of the class in the long run, they did not realize how covering the curriculum would be a challenge in their teaching career. Another important factor that affected their lack of concern about curriculum pace was their unrealistic beliefs about student learning. Accordingly, they did not think about the possible challenges related to implementing national curriculum for the whole year and how it would affect their teaching practices. Lack of concern, optimistic biases, and oversimplification related to curriculum load could be seen in T5 and T3's expressions:

In fact, I don't have much idea about the curriculum or the reality of a rush to cover the curriculum. During the internship, I would be thinking that it would be easy to cover the curriculum since students will understand what you teach immediately.

I had never thought about (curriculum load). I thought I could manage to cover it when I have to. Although I have sometimes little concerns about teaching; whether I would succeed in this profession, I had always believed in myself. I had high self-confidence. I did not focus mainly on the negative sides or possible challenges I could face. For example, I had always 
thought I could modify the curriculum, after started teaching I realized that there are a lot of restrictions on it and now I really have difficulty in covering the curriculum.

On the contrary, there were a few participants who realized that covering the curriculum was an issue for teachers during the observations in the program. Curriculum load was perceived to be something that restricts teachers' practices during internships as T6 mentioned:

During the program and our internships, I noticed the reality of the national curriculum. How to enact it? What does it mean to cover it? Then I understood why teachers had a rush and skip some topics quickly even though I thought it requires much time to teach.

Similar to an overwhelming workload, the curriculum load had also affected participants' choice of methods to teach. Maintaining curriculum pace was perceived to be an obstacle to implementing student-centered activities as T4 asserted. Similarly, T6 had given up the use of technology in her lessons in the rush of covering the curriculum where $\mathrm{T} 7$ was very stressed after doing what seemed right to her in terms of teaching according to students' needs.

During internships, we always prepare activities rather than direct teaching since we believe that in that way students could get the main point of the topic. However, if you do this after in real life, there occurs the problem of covering the curriculum. We have never thought about it during internships.

I might use technology more, integrate it into my lessons, but we cannot do it because of rushing to cover the curriculum. Using technology becomes like wasting time.

If it was needed, I spent my whole class for solving one or two questions. It is because I have idealistic views about teaching. I find it useful. However, this cause pressure and stress. Last year, through the end of the year, I lost sleep over covering the curriculum.

During the program, participants were taught that motivation was key to success. Although their beliefs did not change, they found curriculum load as a restricting factor for doing activities increasing motivation. They tended to give up doing or even not trying what they found effective for students because of maintaining curriculum pace. For example, T2 had stated that the intention to deliver the lesson in an enjoyable way was not realistic because of maintaining curriculum pace. The choice of word "enjoyable" reflects the beliefs of participants about student-centered practices and how it contradicted with their practices in their early careers.

We have to do things to increase the motivation of the students. However, there are obstacles. Like maintaining the curriculum pace... You don't have to rush during the internship. You just focus on the method, which would make your lesson enjoyable and motivate your students. However, it is not the case in reality. If you teach the first period in an enjoyable way, in the next period you have to rush. What do I mean with enjoyable? For example, designing lessons according to multiple intelligence theory, or implementing a group work, or a performance 
task. You cannot do these with every class. They won't give the same reaction. You fail and become demotivated because of the insufficient time (curriculum pace) or the student profile you are working with. Hence expectations do not match with reality.

In addition to influencing participants' teaching methods, the stress of maintaining curriculum pace affected teachers' communication with students and consequently classroom atmosphere as T2 mentioned:

When I fall behind in the curriculum, I become anxious. I became totally intolerable even a small interruption. Students also notice that I am nervous.

School context was a factor affecting the amount of stress when the participant could not catch up with the curriculum. Working in crowded schools was found to be more stressful in terms of catching up with the other classes compared to working in less crowded schools. However, less crowded schools had some disadvantages in terms of support that a teacher could receive. For example, T3 was the only mathematics teacher in her department. Although she could get help from experienced teachers in other departments related to classroom management or communication, she could not get any support in terms of teaching mathematics. Moreover, some other participants had also explained the attitudes of the colleagues as being not supportive. T2 had shared how some colleagues disappointed her in her first year.

We were very idealistic when we first graduated. I was trying to decorate my classroom with mathematical stuff or I was enthusiastic to try new methods. I was preparing reports in detail. However, some colleagues were coming and checking what I was doing and they were like "why do you do things like this? They (administration) would expect us to do the same?". They gave me the feeling that I was doing these in order to stand out among them. Over time, I started doing things more superficially.

\section{Discussion and Conclusion}

This study aims portray the early years' experiences of a group of mathematics teachers. The challenges faced by these participants were interpreted with a holistic approach. With this in mind, the beliefs and expectations behind the challenges, and perceived reasons for those challenges were examined while vicariously revealing challenges. The results will be discussed under the assertions, which also answer research questions.

Assertion 1: Secondary mathematics teachers, in their early careers, mainly have challenges due to lack of mathematics knowledge for teaching, maintaining classroom discipline, dealing with overwhelming workload, lack of students 'motivation towards mathematics lessons, maintaining curriculum pace, keeping records of students' progress, giving performance grades and preparing assessment materials suitable with the level of the students. 
The findings of the study indicate that teachers have challenges due to lack of mathematical knowledge for teaching. Evidently, teachers start their career with inadequate and unsubstantive mathematical knowledge as many studies asserted (Carpenter, Fennema, Petersen, \& Carey, 1998; Cooney, 1999; Feiman-Nemser \& Parker, 1990). As a result, teachers felt insecure in the classroom because of this lack of knowledge. Consequently, this situation both decreases the quality of mathematics instructions and causes classroom discipline problems. This research also shows that participant's belief about mathematical knowledge for teaching consists of facts and procedures, a view collaborated by other studies (Haser \& Star, 2009; Noss \& Baki, 1996). Pre-service teachers, who were once students in teacher-centered classrooms and were taught mathematics with a procedural approach, have constructed strong beliefs about how to be a teacher and teach mathematics (Baki, 2015). It is apparent that before they start their career, they did not realize the importance of substantive mathematical knowledge in other words its correctness, meaning and connectedness (Ball, 1991). Moreover, the results indicated that teachers' lack of knowledge of content and students affect their planning and organizing the lessons and result in the inefficient use of lesson time, and cause their not covering the curriculum. In this regard, the results of this study confirmed the theories that emphasized the fact that utmost importance should be given to teachers' mathematical knowledge for teaching. For example, studies conducted with exemplary mathematics and science teachers provided important signs of quality teaching and stressed the importance of strong content knowledge and pedagogical content knowledge (Tobin \& Fraser, 1989). The current study also revealed that reported challenges related with teaching mathematics were not mainly due to lack of procedural knowledge of teachers but mainly they occurred as a result of lack of conceptual knowledge. However, teachers' specialized content knowledge, which requires conceptual knowledge and understanding, is important in terms of meaningful mathematics learning (Ball \& McDiarmid, 1989). Otherwise, with the lack of conceptual mathematical knowledge, teachers tend to shift their practice from conceptual to procedural and traditional which they feel safe (Hutchinson, 1996). This is, in fact, the way they have been educated during their own schooling and facing many difficulties at the same time in their early career, teachers tend to imitate what they have been exposed to in terms of teaching and learning. In other words, apprenticeship of observation becomes dominant in teachers' decision making when facing challenges without enough support and reflective practice (Lortie, 1975). Another important point is that, due to limited attention capacity, teachers who are dealing with lack of mathematical knowledge for teaching or having classroom management problems are less likely to direct their attention to students learning (Lidstone \& Hollingsworth, 1992). The current study revealed that teachers in their early career mainly focused on being able to answer students' questions or dealt with students' misbehaviors. Students' learning 
was not the main concern for the teachers early in their career. Instead, teachers had mostly task and self-concerns (Fuller \& Bown, 1975; Ryan, 1986).

Some of the challenges the teachers face during their early career should not be regarded as challenges peculiar to novices. Society in the information era changes rapidly, though the needs also change. Accordingly, necessary adjustments are made in the curricula in order to raise individuals answering those needs. For example, probabilistic reasoning and statistics literacy gained a lot of importance in mathematics education (Australian Curriculum, Assessment and Reporting Authority [ACARA], 2010; National Council of Teachers of Mathematics [NCTM], 2002). Although statistics topics were added to Turkish elementary and secondary school curriculum, these topics were limited to simple descriptive statistics concepts. Participants in this study teaching international curricula had taught statistics in depth. However, it is apparent that teacher knowledge and beliefs about statistical and probabilistic reasoning are very limited since they lack education in these fields because not much importance is given to them during their own schooling. Coping with many challenges at the same time, teachers in their early careers had difficulties in the topics that they did have not enough experience as learners. Based upon these, it is important to become adaptive experts. Being an adaptive expert requires efficiency and innovation in teaching. Efficiency requires teaching without giving too many attentional resources to perform tasks and innovation requires being able to move beyond routines, being open to new ideas and practices with questioning existing ones critically (Hammernes et al., 2005). Professional development opportunities should be designed to help both the novice and the experienced teacher gain the skills to become adaptive experts in the rapidly changing society. Nevertheless, a routinized level of teaching is important to reduce the number of attentional foci and become open to novelty in teaching.

The findings also suggested that classroom management was found to be one of the dimensions that teachers confronted consistently as suggested in other studies (Gergin, 2010; Öztürk, 2008). It was revealed that most of the teachers were not expecting to experience substantial difficulty in classroom management. However, they faced classroom management problems during initial years. As a matter of fact, classroom management was also recognized as an unexpected problem by novice teachers in Turkey's national curriculum context as well as in international studies (Haser, 2010; Nahal, 2010). In-service teachers, before they have started their career, did not seem to have acknowledged that pedagogical content knowledge, lesson preparation or their physical or emotional mood would affect their power in managing the classroom

In addition, the study revealed that participants had been challenged in keeping track of students' performances, giving performance grades and preparing examinations. 
Similarly, none or non-systematic ways of keeping records of students' progress was revealed in a study conducted with Turkish mathematics teachers (Türnüklü, 2003). Hence, in this study, it was noticed that participants had quickly reorganized the way that they had used to keep track and give performance grades after they had seen the pitfalls of their early applications.

Moreover, it was revealed that heavy workload and lack of time management is a challenge affecting teachers' early careers (Fantilli \& McDougall, 2009; Kozikoğlu, 2016; Öztürk, 2008). Heavy workload had caused burn-out syndrome, decrease in motivation for lesson preparation (Fullan \& Hargreaves, 1991). The study also showed that maintaining curriculum pace was a factor that had affected participants'performances and teaching philosophy in their early career. This overlaps with constructivist ideas of teaching mathematics replacing itself with direct teaching methods due to maintaining curriculum pace. Participants believed that they could maintain curriculum pace without direct teaching. Teachers had felt pressure under the rigid timeline of the curriculum, which were created to standardize instructional practices and ensured broad coverage (Brooks \& Brooks, 1999). One of the areas that teachers' accountability was questioned in Turkey was related to covering the curriculum and it was interesting that the stress was not mentioned in the domains like students' achievement in the exams or their academic performances. The one-size-fits-all approach in the national curriculum restricted teachers to pre-determined times to cover each unit and this is a stress for not only novices but also experienced teachers.

Assertion 2: Teachers have oversimplified beliefs, unrealistic expectations about teaching and this is apparent in the challenges that they face.

Reflections on challenges revealed another important finding as the mismatch between expectations and realities affecting teachers' early careers as a factor. In most of the areas that teachers face challenges, there exists a disparity between what teachers expected before they started their career and what they really experienced afterwards. One of the reasons that participants experienced reality shocks can be due to unrealistic high self-efficacy beliefs formed by vicarious experiences. Vicarious experiences are a source of self-efficacy belief, which is formed by modeling other people behaviors. They persuade themselves that if others can do it, they should be able to achieve at least some improvement in performance (Bandura \& Barab, 1973). However, without reflecting in depth about their own status of knowledge of teaching and competencies, it turns out to be oversimplifying the profession and become a source of reality shock. An alternative explanation could be teachers' main focus of attention at the beginning of the career. Teachers' expectations from themselves are to help students' learn which could be also regarded as a part of fantasy stage and they may simply disregard possible challenges that would hinder their efforts in 
these fantasy world of teaching in their beliefs. This expectation is replaced quickly with the mode of survival causing a great deal of stress with a lot of concerns related to class control, or content knowledge (Fuller \& Bown, 1975). It is important for the student teachers to perceive that teaching involves many complexities and the teachers must develop a more holistic view of teaching and classroom. Simplistic views about the profession and disregarding the complexity would lead to unrealistic optimism, which may have serious implications for teacher education. In addition to these, studies on exemplary teachers again revealed that exemplary teachers have a more complex view of teaching compared to non-exemplary teachers (as cited in Berliner, 2001). Simplistic views about the profession and disregarding complexity would lead to unrealistic optimism, which would have serious implications for teacher education. The results supported the findings of the study of Weinstein (1988), which revealed that pre-service teachers had optimistic biases in various domains of teaching and brough these biases to their early career. Either they did not have a concern, or even if they thought about the possible challenges, they simply were convinced that they could overcome them. However, these simplistic and unrealistic thoughts about teaching lead to the realization of how challenging and complicated teaching can be as teachers go through struggles in their early career. Simplistic beliefs during pre-service teacher education would cause less reflective teaching, less focused observations of teaching and learning processes. Based upon these, it is important that student teachers perceive that teaching involves many complexities and must have a more holistic view of teaching and classroom.

Assertion 3: Teachers begin to have a more complex and connected schema about teaching when they begin to see how different dimensions of teaching affect each other when they start reflecting on the challenges.

The results indicate that teachers cannot envision the relationship between different dimensions of teaching profession before they start their careers. In other words, they have the problem of integrating various components of complex classroom reality (Eilam \& Poyas, 2009). They have vague ideas before they start their career about how their subject area knowledge can affect their classroom management or how lesson planning is crucial for their self-confidence in teaching. In contrast, skilled teachers know that management problems do not usually occur in isolation from the lesson being taught (Lidstone \& Hollingsworth, 1992). Moreoever, the effects of contextual factors are unclear and optimistic biases hinder the possible contextual challenges and their affect on other dimensions of teaching before they start their career. One of the reasons why pre-service teachers have a less connected schema of teaching could be their limited cognitive attention capacity. The results showed that teachers, in their early career, had mostly self-concerns and an attention to students' learning and impact could not be found in the teachers' primary challenges they focused on since they had just started to newly develop a more 
interconnected schema of teaching and begun to realize why these challenges occur (Ryan, 1986). Although school experiences during teacher education programs was giving the opportunity to examine the complexity of real classrooms, it might not turn out to be a platform for integrating different components of teaching because of lack of productive reflection on the critical moments of the lessons they observed or taught. Another reason of lacking an awareness of this complex nature of teaching could be the separation of the method courses and foundation courses, as well as the separation between course-work and field-work (Grossman, Hammerness, \& McDonald, 2009). This situation was ambigious in terms of realistic preparation since teaching experiences were not as fragmented as they were offered in the teacher preparation programs (Korthagen, 2001)

Assertion 4: The mismatch between teachers' beliefs and practices indicates a theory-practice gap.

One of the important findings of the current study is washed out experiences of teachers in their early career supporting various researchers. Teachers' perception about theory becomes somehow useless and inapplicable in the early career. There can be teacher-related and context-related reasons for this situation. Context-related reasons can be the existence of high-stake national exams, national curriculum constraints, and the lack of colleague or administrative support. However, there are teacher-related constraints. The reasons for this can be the broad generalizations teachers make after the failure of a few attempts to integrate theory into practice so "the perceived gap between theory and practice originates not so much from demonstrable mismatches between ideal and practice but from the experience of being held accountable for them." (Elliot, 1997, p. 97).

The study showed that teachers come across contextual challenges that could result from the characteristics of the school they worked at, the national curriculum, the national exams, the students' profiles, or the overwhelming workload. When the contextual constraints interfere with lack of knowledge and skills of teaching, teachers tend to attribute the sources of many challenges to contextual reasons. The causal perceptions may vary across different individuals and it is important in terms of the effort they would show in order to overcome the problems. Thus, whether the locus of control beliefs of teachers in other word; whether they believe the cause of events is internal or external is important in terms of the effort they put in their work (Strauser, Ketz, \& Kim, 2002).

The results showed that although pre-service teachers may shift their traditional beliefs to non-traditional beliefs about teaching during teacher education programs, after they start their career, their practices become traditional. One of the reasons for this discrepancy between beliefs and practices would be teachers holding surface beliefs of non-traditional beliefs rather than deep beliefs (Kaplan, 1991). Under various contextual difficulties, teachers' surface beliefs do not reflect on their practices. 
Teachers' beliefs and expectations stand as lenses for their educational courses and their practices. Teacher education programs should take into consideration the beliefs of the pre-service teachers and shape the teacher education programs in order to address the needs and to change the cognitive schema of teachers from a simpler, less connected form to a more complex and sophisticated schema of teaching profession. The results of the current study confirm that pre-service teachers tend to disregard the complexities of teaching and underestimate the impact of the possible challenges that they may face with unrealistic optimism. Thus, they need to reflect more productively on the challenges that they may face. Field expreiences, which takes place during their training, is a good opportunity to become aware of these possible challenges. However, they may not be aware of the complexities when they observe expert teachers. In addition to these, teaching with the existence of a mentor would be different than being alone in the classroom because the full responsibility of a classroom differs from the experiences during internship. Thus, these field experiences can be supported by case-based discussions. These cases, which reflect the reality and complexity of the classroom, would provide opportunities for reflection, and reflective practices were found to be fruitful in terms of bridging links between theory and practice. (Hammond \& Collins, 1991; Jay \& Johnson, 2002; Ünver, 2014) Moreover, creating reflection opportunities by using real teaching practices and cases would facilitate pre-services linking theory to practice that would shape teachers' work explicitly and implicitly (Ball \& Forzani, 2009). Regarding the importance of mathematical knowledge for mathematics teaching, the cases would be more helpful if they reflected the specific reality of a mathematics classroom. Therefore, cases would better have a mathematical content in the core (Barnett, 1991; Merseth, 2003). Case-based discussions would be also helpful to build learning communities. In other words, pre-service teachers would have the opportunity to understand how different points of view would open their minds and contribute to their reflective practice (Lin, 2002). Another advantage of case-based discussion would be the situated nature of the cases. Cases that reflect the realities of the context that pre-service teachers are likely to teach would be valuable in terms of giving them the opportunity to reflect on the constraints that the context will bring before they personally experience them. As a matter of fact, they would have more realistic expectations about the context they would teach in. Research on teacher cognition also shows that teachers' knowledge and beliefs influence what they determine as important to attend to in complex situations (Schoenfeld, 1998). For example, teachers of mathematics reasoning about a classroom interaction from a mathematics classroom would differ than their reasoning a literature or science classroom (van Es \& Sherin, 2002). Similarly, a subject-specific professional development opportunity would be more relevant for both experienced and novice teachers. In this respect, lesson study would be an important learning opportunity for all mathematics teachers, especially for newly 
qualified ones. Lesson study, originated as a Japanese professional development model, is a collaborative work that teachers formulate goals, accordingly planning a research lesson, collecting data during research lesson, reflect on the various dimensions of the lesson and iterate the process (Lewis, Perry, \& Murata, 2006). It has the potential to advance novice teachers' skills and expand their repertoire of teaching via the collaboration between experienced and novice teachers (Fernandez, Cannon, \& Chokshi, 2003; Moir \& Gless, 2001).

It is unfair to expect effective teaching from novices when they have the same or even greater responsibilities relative to experienced teachers (Bartell, 2005; Feiman-Nemser, 2001). This research showed that teachers needed more time to prepare for their lessons in order to overcome the lack of knowledge and skills related to teaching. Thus, teachers' schedules should be arranged in a way that allow them time to prepare for their lessons, collaborate with other teachers, and reflect on their practices. In this process, effective induction was shown to be critically important in teachers' professional growth (Clift \& Brady, 2005; Cohen \& Fuller, 2006). Both school administrators and policy-makers must acknowledge the fact that teacher education should be supported with effective induction periods. There would be a smoother transition to the career if there was an induction period provided for novice teachers (Dean, 2016). However, one of the reasons for the struggles of beginner teachers is the lack of induction periods. It would be a delusion to expect that pre-service education, no matter how intense, comprehensive, and practice-based, has fully prepared the teacher for this relentless career. Regarding the fact that learning to teach was a continuous process, beginning teachers should continue to learn about teaching via in-service professional development processes (FeimanNemser, 2001). Nevertheless, the induction period is crucial in terms of maintaining this continuum. Mentors in this period are of utmost importance in the development of a beginning teacher. However, it is reported that mentoring and induction are not well established in many schools, even in private, competitive schools (Özoğlu, 2010). Working with mentors, reflecting on their experiences, having time to be fully prepared for their lessons would decrease the amount of stress that they have and challenges would subside. However, they would turn these challenges into learning opportunities during an induction period. The Ministry of Education in Turkey launched an induction program in February 2016. A research was conducted with the first cohort who passed the MONE candidate teacher-training process. The results of this study revelaed that although the participants endorsed the induction program, there were two important aspects reducing its effectiveness: the excessive number of forms that must be filled during the process; and the quality of the mentors (İlyas, Coşkun, \& Toklucu, 2017). Most of the activities implemented in this induction process displayed similarities with the program that participants of the current study had undertaken. For this reason, the results of this study would provide insights for improving this induction program. 
Expertise is not a natural consequence of experience. Teachers who begin their careers with lack of support and have limited professional development opportunities in their career, if do not quit the profession, will gain the experience but will neither become an expert nor turn out to be one of the exemplary figures in the profession (Berliner, 2001). The teachers, who are idealistic and self-motivated to improve themselves, would find opportunities to become better teachers. However, leaving it to teachers' characteristics should not be the only solution. Through professional development opportunities, teachers should be encouraged. The first years in a career have considerable impact on the following phases of the career. Although the current study has several implications for teacher educators and policy-makers in terms of inservice and pre-service training, this study is limited to participants' verbal responses. Further studies would take a more longitudinal approach to early career experiences of mathematics teachers including classroom observations, other stakeholders' viewpoints besides teachers' own perceptions. Getting to know more about what teachers experienced would provide more opportunities to help pre-service teachers to develop a more realistic and holistic view of teaching mathematics and developing professional development programs to help in-services to become adaptive experts.

\section{References}

Akın, S., Yıldırım, A., \& Goodwin, A. L. (2016). Classroom management through the eyes of elementary teachers in Turkey: A phenomenological study. Educational Sciences: Theory \& Practice, 16, 771-797. http://dx.doi.org/10.12738/estp.2016.3.0376

Australian Curriculum, Assessment and Reporting Authority. (2010). Australian Curriculum: Mathematics, Version 1.1. Retrieved from https:/www.australiancurriculum.edu.au/f-10curriculum/mathematics/pdf-documents/

Baki, A. (2015). Kuramdan uygulamaya matematik eğitimi [Mathematics education from theory into practice]. Ankara, Turkey: Harf Eğitim Yayıncılık.

Ball, D. L. (1991). Research on teaching mathematics: Making subject-matter knowledge part of the equation. In J. E. Brophy (Ed.), Advances in research on teaching: Vol. 2. Teachers' knowledge of subject-matter as it relates to their teaching practice (pp. 1-48). Greenwich, CT: JAI Press.

Ball, D. L., \& Forzani, F. M. (2009). The work of teaching and the challenge for teacher education. Journal of Teacher Education, 60(5), 497-511.

Ball, D. L., \& McDiarmid, G. W. (1989). The Subject Matter Preparation of Teachers. Issue Paper 89-4. East Lansing, MI: Michigan State University, National Center for Research on Teacher Education.

Ball, D. L., Thames, M. H., \& Phelps, G. (2008). Content knowledge for teaching: What makes it special? Journal of Teacher Education, 59(5), 389-407. http://dx.doi. org/10.1177/0022487108324554

Bandura, A., \& Barab, P. G. (1973). Processes governing disinhibitory effects through symbolic modeling. Journal of Abnormal Psychology, 82, 1-9.

Barnett, C. (1991). Building a case-based curriculum to enhance the pedagogical content knowledge of mathematics teachers. Journal of Teacher Education, 42(4), 263-272. https://doi. org/10.1177/002248719104200404 
Bartell, C. A. (2005). Cultivating high quality teaching through induction and mentoring. Thousand Oaks, CA: Corwin Press.

Baydar, S. C., \& Bulut, S. (2002). Öğretmenlerin matematiğin doğası ve öğretimi ile ilgili inançlarının matematik eğitimindeki önemi [Importance of teachers' beliefs about nature of mathematics and teaching of mathematics in mathematics education]. Hacettepe University Journal of Education, 23, 62-66.

Berliner, D. C. (2001). Learning about and learning from expert teachers. International Journal of Educational Research, 35, 463-482. https://doi.org/10.1016/S0883-0355(02)00004-6

Borko, H., \& Livingston, C. (1989). Cognition and improvisation: differences in mathematics instruction by expert and novice teachers. American Educational Research Journal, 26, 473-498. https://doi.org/10.3102/00028312026004473

Bransford, J. (1979). Human cognition: Learning understanding and remembering. Belmont, CA: Wadsworth.

Brooks, J. G., \& Brooks, M. G. (1999). In search of understanding the case for constructivist classrooms. Alexandria, VA: Association for Supervision \& Curriculum Development.

Bullough, R. (1989). First year teacher: A case study. New York, NY: Teachers College Press.

Bümen, N. T. (2010). The relationship between demographics, self-efficacy, and burnout among teachers. Eurasian Journal of Educational Research, 40, 17-36.

Çakıroğlu, E., \& Çakıroğlu, J. (2003). Reflections on teacher education in Turkey. European Journal of Teacher Education, 26(2), 253-264. https://doi.org/10.1080/0261976032000088774

Carpenter, T. P., Fennema, E., Peterson, P. L., \& Carey, D. A. (1988). Teachers' pedagogical content knowledge of students' problem solving in elementary arithmetic. Journal for Research in Mathematics Education, 19, 385-401. http://doi.org/10.2307/749173

Clarke, D., \& Hollingsworth, H. (2002). Elaborating a model of teacher professional growth. Teaching and Teacher Education, 18(8), 947-967. https://doi.org/10.1016/S0742-051X(02)00053-7

Clift, R. T., \& Brady, P. (2005). Research on methods courses and field experiences. In M. CochranSmith \& K. Zeichner (Eds.), Studying Teacher Education: The report of the AERA Panel on Research and Teacher Education (pp. 309-424). Mahwah, NJ: Erlbaum.

Cohen, B., \& Fuller, E. (2006, April). Effects of mentoring and induction on beginning teacher retention. Paper presented at the annual meeting of the American Educational Research Association, San Francisco, CA.

Cooney, T. J. (1999). Conceptualizing teachers' way of knowing. Educational Studies in Mathematics, 38, 163-187. https://doi.org/10.1023/A:1003504816467

Darling-Hammond, L. (1999). Teacher quality and student achievement: A review of state policy evidence. Seattle: Center for the Study of Teaching and Policy. http://dx.doi.org/10.14507/epaa. v8n1.2000

Dean, H. (2016). Exploring novice teachers' perceptions of the impact of an induction program: A qualitative case study (Doctoral dissertation, Texas Tech University).

Dede, Y., \& Karakuş, F. (2014) The effect of teacher training programs on pre-service mathematics techers' beliefs towards mathematics. Educational Sciences: Theory \& Practice, 14, 791-813. Retrieved from https://files.eric.ed.gov/fulltext/EJ1038788.pdf

Denzin, N. K., \& Lincoln, Y. S. (2005). The SAGE Handbook of Qualitative Research, (3rd ed.). Thousand Oaks, CA: Sage Publications. 
Department for Education and Skills. (2005). Statistics of education: School workforce in England 2004 edition. London, UK: Authors.

DeRosa, L. (2016). Beginning teachers: The connection between expectations and job satisfaction (Doctoral dissertation, Southern New Hampshire University). Retrieved from https://academicarchive. snhu.edu/bitstream/handle/10474/2921/sed2016derosa.pdf?sequence=3\&isAllowed=y

Eilam, B., \& Poyas, Y. (2009) Learning to teach: Enhancing pre-service teachers' awareness of the complexity of teaching-learning processes. Teacher and Teaching: Theory and Practice, 15(1), 87-107. https://doi.org/10.1080/13540600802661337

Elliot, J. (1991). Action research for educational change. Philadelphia: Open University Press.

Ernest, P. (1989). The knowledge, beliefs and attitudes of the mathematics teacher: A model. Journal of Education for Teaching, 15(1), 13-33. https://doi.org/10.1080/0260747890150102

Fantilli, R. D., \& McDougall, D. E. (2009) A study of novice teacher: Challenges and supports in the first years. Teaching and Teacher Education, 25, 814-825. https://doi.org/10.1016/j.tate.2009.02.021

Feiman-Nemser, S. (2001). From preparation to practice: Designing a continuum to strengthen and sustain teaching. Teachers College Record, 103, 1013-1055. https://doi.org/10.1016/j.tate.2009.02.021

Feiman-Nemser, S., \& Parker, M. B. (1990). Making subject matter part of the conversation or helping beginning teacher to learn to teach. East Lansing, MI: National Center for Reasearch on Teacher Education.

Fernandez, C., Cannon, J., \& Chokshi, S. (2003). A US-Japan lesson study collaboration reveals critical lenses for examining practice. Teaching and Teacher Education, 19, 171-185. https:// doi.org/10.1016/S0742-051X(02)00102-6

Fisher, M. H. (2011). Factors influencing stress, burnout, and retention of secondary teachers. Current Issues in Education, 14(1). Retrieved from http://cie.asu.edu/

Fogarty, J. L., Wang, M. C., \& Creek, R. (1982, March). A descriptive study of experienced and novice teachers' interactive instructional decision processes. Paper presented at the annual meeting of the American Educational Research Association, New York City. Retrieved from http://www.jstor.org/stable/27540012

Fullan, M. G., \& Hargreaves, A. (1991). What's worth fighting for: Working together for your school. Toronto: Ontario Public School Teachers Association

Fuller, F., \& Bown, O. (1975). Becoming a teacher. In K. Ryan (Ed.), Teacher Education (74th Yearbook of the National Society for the Study of Education (Part 2, pp. 25-52). Chicago, IL: University of Chicago Press.

Gavish, B., \& Friedman, I. A. (2010). Novice teachers' experiences of teaching: A dynamic aspect of burnout. Social Psychology of Education, 13(2), 141-167. https://doi.org/10.1007/s11218-009-9108-0

Gergin, E. (2010). Mesleğe yeni başlayan öğretmenlerin ilk yıllarda karşılaştığı zorluklar ve bu zorluklarla başa çıkma yolları [Problems that beginning teachers face in the first years of teaching and their ways to overcome these problems] (Master's thesis, Marmara University, İstanbul, Turkey). Retrieved from https://tez.yok.gov.tr/UlusalTezMerkezi/

Glaser, B. G., \& Strauss, A. L. (1967). The discovery of grounded theory: Strategies for qualitative research. Hawthorne, NY: Aldine.

Gordon, R., Kane, T. J., \& Staiger, D. O. (2006). Identifying effective teachers using performance on the job. Washington, DC: The Brookings Institution. 
Gordon, S. P., \& Maxey, S. (2000). How to help beginner teachers succeed. Alexandria, VA: Association for Supervision and Curriculum Development.

Grossman, P., Hammerness, K., \& McDonald, M. (2009). Redefining teaching, reimagining teacher education. Teachers and Teaching: Theory and Practice, 15(2), 273-289. https://doi. org/10.1080/13540600902875340

Gündüz, B. (2005). İlköğretim öğretmenlerinde tükenmişlik [Burnout of teachers in elementary education]. Mersin University Eğitim Fakültesi Dergisi, 1(1), 152-166. Retrieved from http:// dergipark.ulakbim.gov.tr/mersinefd/article/viewFile/5000003033/5000003566

Hammerness, K., Darling-Hammond, L., Bransford, J., Berliner, D., Cochran-Smith, M., McDonald, M., ... Zeichner, K. (2005). How teachers learn and develop. In L. Darling-Hammond \& J. Bransford (Eds.), Preparing teachers for a changing world: What teachers should learn and be able to do (pp. 358-389). San Francisco, CA: Jossey-Bass.

Hammond, M., \& Collins, R. (1991). Self-directed learning. London, UK: Kogan Page.

Haser, Ç. (2010). Learning to teach in the national curriculum context. European Journal of Teacher Education, 33, 289-302. https://doi.org/10.1080/02619761003713894

Haser, C., \& Star, J. R. (2009). Change in beliefs after first year of teaching: The case of Turkish national curriculum context. International Journal of Educational Development, 29(3), 293-302. https://doi.org/10.1016/j.ijedudev.2008.08.007

Hill, H. C., Rowan, B., \& Ball, D. L. (2005). Effects of teachers' mathematical knowledge for teaching on student achievement. American Educational Research Journal, 42(2), 371-406. https://doi.org/10.3102/00028312042002371

Hollingsworth, S. (1989). Prior beliefs and cognitive change in learning to teach. American Educational Research Journal, 26(2), 160-189. https://doi.org/10.3102/00028312026002160

Hutchinson, E. (1996). Preservice teachers' knowledge: A contrast of beliefs and knowledge of ratio and proportion (Doctoral Dissertation, University of Wisconsin-Madison).

İlyas, İ. E., Coşkun, İ., \& Toklucu, D. (2017). SETA Candidate teacher training model monitoring and evaluation report in Turkey. İstanbul, Turkey: Turkuvaz Communication and Publishing. https://dx.doi.org/10.16986/HUJE.2018037027

Jay, K. J., \& Johnson, K. L. (2002). Capturing complexity: A typology of reflective practice for teacher education. Teaching and Teacher Education, 18, 73-85. Retrieved from https:// teachsource.files.wordpress.com/2013/05/jay-and-johnson-on-reflection.pdf

Kagan, D. M. (1992a). Professional growth among pre-service and beginning teachers. Review of Educational Research, 62(2), 129-169. Retrieved from http://www.jstor.org/stable/1170578

Kagan, D. M. (1992b). Implication of research on teacher belief. Educational psychologist, 27(1), 65-90. https://doi.org/10.1207/s15326985ep2701_6

Kaplan, R. G. (1991, October). Teacher beliefs and practices: A square peg in a square hole. Proceedings of the annual meeting of the North American Chapter of the International Group for the Psychology of Mathematics Education, Blacksburg, VA.

Khasaka, M. M. O. C., \& Berger, M. (2016). Status of teachers' proficiency in mathematical knowledge for teaching at secondary school level in Kenya. International Journal of Science and Mathematics Education, 14(2), 419-435. https://doi.org/10.1007/s10763-015-9630-9

Kim, Y. (2013). Teaching mathematical knowledge for teaching: Curriculum and challenges (Doctoral dissertation, University of Michigan). Retrieved from https://deepblue.lib.umich.edu/ handle/2027.42/97937 
Kocadere, S. A., \& Aşkar, P. (2013). Okul uygulamaları derslerine ilişkin görüşlerin incelenmesi ve bir uygulama modeli önerisi [A review of views about student teaching courses and an application model proposal]. Hacettepe Üniversitesi Ĕ̆itim Fakültesi Dergisi, 28(2), 27-43. Retrieved from http:/www.efdergi.hacettepe.edu.tr/yonetim/icerik/makaleler/165-published.pdf

Korthagen, F. (2001). Reflection on reflection. In F. A. J. Korthagen, J. Kessels, B., Koster, B. Lagerwerf, \& T. Wubbels (Eds.), Linking practice and theory: The pedagogy of realistic teacher education (pp. 51-68). Mahwah, NJ: Lawrence Erlbaum.

Kozikoğlu, İ. (2016). Öğretimin ilk yllı: Mesleğin ilk yılındaki öğretmenlerin karşılaştıkları güçlükler, hizmet öncesi eğitim yeterlikleri ve mesleğe adanmışlıklarl [First year in teaching: Challenges faced by novice teachers, their pre-service education's competency and commitment to the profession] (Doctoral Dissertation, Yüzüncü Yıl University, Van, Turkey). Retrieved from https://tez.yok.gov.tr/UlusalTezMerkezi/

Levin, B. B. (2003). Case studies of teacher development: An in-depth look at how thinking about pedagogy develops over time. Mahwah, NJ: Lawrence Erlbaum.

Lewis, C., Perry, R., \& Murata, A. (2006). How should research contribute to instructional improvement? The case of lesson study. Educational Researcher, 35(3), 3-14. Retrieved from http://www.jstor.org/stable/3700102

Lidstone, M. L., \& Hollingsworth, S. (1992). A longitudinal study of cognitive change in beginning teachers: Two patterns of learning to teach. Teacher Education Quarterly, 19(4), 39-57. Retrieved from http://www.jstor.org/stable/23475135

Lin, P. J. (2002). On enhancing teachers' knowledge by constructing cases in classrooms. Journal of Mathematics Teacher Education, 5, 317-349.

Lincoln, Y. S., \& Guba, E. G. (1985). Naturalistic inquiry. Beverly Hills, CA: Sage.

Lortie, D. (1975). Schoolteacher: A sociological study. London, UK: University of Chicago Press.

Matthews, B., \& Ross, L. (2010). Research methods: A practical guide for the social sciences. Italy: Pearson.

Merseth, K. K. (Ed.). (2003). Windows on teaching math: Cases of middle and secondary classrooms. New York, NY: Teachers College Press.

Moir, E., \& Gless, J. (2001). Quality induction: An investment in teachers. Teacher Education Quarterly, 28(1), 109-114. Retrieved from http://www.jstor.org/stable/23478338

Nahal, S. P. (2010). Voices from the field: Perspectives of first-year teachers on the disconnect between teacher preparation programs and the realities of the classroom. Research in Higher Education Journal, 8(1), 1-19. Retrieved from https://www.researchgate.net/publication/242758013 Voices_from_the_Field_Perspectives_of_First-year_Teachers_on_the_Disconnect_between Teacher_Preparation_Programs_and_the_Realities_of_the_Classroom

National Commission on Teaching \& America's Future. (2003). No dream denied: A pledge to America's children. New York, NY: National Commission on Teaching \& America's Future.

National Council of Teachers of Mathematics. (2002). Principles and standards for school mathematics. Reston, VA: Authors.

Noss, R., \& Baki, A. (1996). Liberating school mathematics from procedural view. Hacettepe University Journal of Education, 12,179-182. Retrieved from http://dergipark.gov.tr/download/article-file/88162

Organization for Economic Co-operation and Development. (2009). Creating effective teaching and learning environments: First results from TALIS. Paris, France: Author. Retrieved from http://www.oecd.org/education/school/43023606.pdf 
Özcan, M. (2012). Okulda üniversite modelinde kavramsal çerçeve: Eylemdeki vizyon [Conceptual framework: Vision in action in the model of university within school]. Journal of Teacher Education and Educators, 1(1), 107-132. Retrieved from https://www.researchgate.net/ publication/264973302_Okulda_Universite_Modelinde_Kavramsal_Cerceve_Eylemdeki_Vizyon_ Conceptual_Framework_Vision_in_Action_in_the_Model_of_University_within_School

Özoğlu, M. (2010). Türkiye'de öğretmen yetiştirme sisteminin sorunlarl [The problems of teacher education system in Turkey]. Retrieved from http://www.setav.org/ups/dosya/20275.pdf

Öztürk, M. (2008). Induction into teaching: Adaptation challenges of novice teachers (Master's Thesis, Middle East Technical University, Ankara, Turkey). Retrieved from https://tez.yok.gov. tr/UlusalTezMerkezi/

Öztürk, M., \& Y1ldırım, A. (2013). Adaptation challenges of novice teachers. Hacettepe University Journal of Education, 28(1), 294-307. Retrieved from http://dergipark.ulakbim.gov.tr/hunefd/ article/download/5000048062/5000045383

Pajares, M. F. (1992). Teachers' beliefs and educational research: Cleaning up a messy construct. Review of Educational Research, 62(3), 307-332. Retrieved from http://www.jstor.org/stable/1170741

Pigge, F. L., \& Marso, R. N. (1997). A seven-year longitudinal multi-factor assessment of teaching concerns development through preparation and early years of teaching. Teaching and Teacher Education, 13(2), 225-235. https://doi.org/10.1016/S0742-051X(96)00014-5

Raymond, A. (1997). Inconsistency between a beginning elementary school teacher's mathematics beliefs and teaching practice. Journal for Research in Mathematics Education, 28(5), 550-576. https://doi.org/10.2307/749691

Richardson, V. (1996). The role of attitudes and beliefs in learning to teach. In J. Sikula (Ed.), Handbook of research on teacher education ( $2^{\text {nd }}$ ed. pp. 102-119). New York, NY: Macmillan.

Rokeach, M. (1968). Belief, attitude and values. San Franciso, CA: Jossey-Bass.

Ryan, K. (1986). The Induction of New Teachers. Fastback 237. Bloomington, IN: Phi Delta Kappa. Retrieved from https://files.eric.ed.gov/fulltext/ED268117.pdf

Schoenfeld, A. H. (1998). Toward a theory of teaching-in-context. Issues in Education, 4(1), 1-94. https://doi.org/10.1016/S1080-9724(99)80076-7

Schulman, L. (1986). Those who understand: Knowledge growth in teaching. Educational Researcher, 15(2), 4-14. Retrieved from http://www.jstor.org/stable/1175860

Strauser, D. R., Ketz, K., \& Keim, J. (2002). The relationship between self-efficacy, locus of control and work personality. Journal of Rehabilitation, 68, 20-26.

Taneri, P. O., \& Ok, A. (2014). Alandan ve alan dışından öğretmenlik sertifikası ile atanan yeni sınıf öğretmenlerinin sorunları [The problems of novice classroom teachers having regular and alternative certificates]. Education and Science, 39(173), 418-429. Retrieved from http:// egitimvebilim.ted.org.tr/index.php/EB/article/view/1569

Thompson, A. G. (1984). The relationship of teachers' coneptions of mathematics and mathematics teaching to instructional practice. Educational Studies in Mathematics, 15(2), 105-127. Retrieved from http://www.jstor.org/stable/3482244

Tobin, K., Fraser, F. J. (1989). Case studies of exemplary science and mathematics teaching. School Science and Mathematics, 89(4), 320-334. Retrieved from https://onlinelibrary.wiley.com/doi/ pdf/10.1111/j.1949-8594.1989.tb11927.x 
Tümkaya, S. (1996). Öğretmenlerdeki tükenmişlik, görülen pikolojik belirtiler ve başa çıkma davranışları [Psychological Symptoms of Burnout and Coping Behaviors in Teachers] (Doctoral Dissertation, Çukurova University, Adana, Turkey).

Türnüklü, E. B. (2003) Türkiye ve İngiltere'deki matematik öğretmenlerinin değerlendirme biçimleri [Mathematics teachers' assessment styles in Turkey and England]. Hacettepe University Journal of Education, 24, 108-118.

Ünver, G. (2014). Connecting theory and practice in teacher education: A case study. Educational Sciences, Theory \& Practice, 14, 1402-1407. Retrieved from https://files.eric.ed.gov/fulltext/ EJ1045035.pdf

van Es, E. A., \& Sherin, M. G. (2002). Learning to notice: Scaffolding new teachers' interpretations of classroom interactions. Journal of Technology and Teacher Education, 10(4), 571-596. Retrieved from https://www.learntechlib.org/primary/p/9171/

Veenman, S. (1984). Perceived problems of beginning teachers. Review of Educational Research, $54,143-178$.

Voss, T. Kleickman, T., Kunter, M., \& Hachfeld, A. (2013). Mathematics Teachers' Beliefs. In M. Kunter, J. Baumert, W. Blum, U. Klusmann, S. Krauss \& M. Neubrand (Eds.), Cognitive activation in the mathematics classroom and professional competence of teachers. results from the coactiv project (pp. 235-57). New York, NY: Springer.

Wayne, A. J., \& Youngs, P. (2003). Teacher characteristics and student achievement gains: A review. Review of Educational Research, 73(1), 89-122. Retrieved from http://www.jstor.org/ stable/3516044

Weinstein, C. S. (1988). Pre-service teachers' expectations about the first year of teaching. Teaching and Teacher Education, 4, 31-40. https://doi.org/10.1016/0742-051X(88)90022-4

Westerman, D. A. (1991). Expert and novice teacher decision-making. Journal of Teacher Education, 42(4), 292-305. https://doi.org/10.1177/002248719104200407

Yanık, H. B., Bağdat, O., Gelici, Ö., \& Taştepe, M. (2016). Göreve yeni başlayan ortaokul matematik öğretmenlerinin karşılaştıkları sorunlar [Challenges that beginning middle school mathematics teacher's face]. Mustafa Kemal University Journal of Social Studies Institute, 13(36), 130-152. Retrieved from http://sbed.mku.edu.tr/article/view/5000186820 